\title{
ECN N-TYPE SILICON SOLAR CELL TECHNOLOGY: AN INDUSTRIAL PROCESS THAT YIELDS 18.5\%
}

\author{
R.C.G. Naber, N. Guillevin, A.R. Burgers, L.J. Geerligs, A.W. Weeber \\ ECN Solar Energy \\ PO Box 1, 1755 ZG Petten, The Netherlands
}

\begin{abstract}
There is currently much interest in n-type solar cells because of the advantages of this material. N-type material is expected to be more favourable for obtaining high efficiencies than p-type doped substrates. We have developed a process for n-type solar cells for large area multicrystalline and monocrystalline silicon wafers. The production process is based on industrial processing steps such as screen-printed metallization and firing through. The surfaces of these cells are passivated with a layer stack consisting of $\mathrm{SiO}_{2}$ and $\mathrm{SiN}_{\mathrm{x}}$ where the former is created by a wet chemical process and the latter by inline PECVD. We demonstrate that the surface passivation can be improved with an alternative wet chemical process for creating the $\mathrm{SiO}_{2}$ layer. This new process results in an enhancement of the implied $V_{\text {oc }}$ of unmetallized cells as measured by quasi-steady-state photoconductance (QSSPC) and the $\mathrm{V}_{\mathrm{oc}}$ of completed cells. The process improvements have yielded a new record efficiency of $18.5 \%$ (for a particular rear reflection surface) that was independently confirmed by Fraunhofer ISE CalLab.
\end{abstract}

\section{INTRODUCTION}

N-type silicon has been proven to have a higher tolerance to common transition metal impurities, such as those present in silicon produced from quartz and carbon. This tolerance could potentially result in higher minority carrier diffusion lengths compared to p-type substrates $[1,2]$. Boron-oxide defects that lead to light-induced degradation are also absent. In spite of these advantages, at present, more than $85 \%$ of the silicon solar cells produced by the industry are based on p-type substrates. This is caused mostly by an insufficient development and industry implementation of n-type cell processes.

One of the major development areas of the n-type $\mathrm{Si}$ solar cell process remains the passivation of the front side boron emitter. Since the conventional way to passivate $\mathrm{n}+$ emitters for the p-type solar cell process, using a PECVD-SiNx layer, results in a poor or no passivation for $\mathrm{p}+$ emitters, a new way of passivating $\mathrm{p}+$ surfaces needs to be developed. Mihailetchi et al. [3] have developed a new method to passivate $p+$ emitters which brought new potential to the n-type $\mathrm{Si}$ industrial solar cell process. This method relies on the same PECVD SiNx technology as is widely used in industry to passivate $\mathrm{n}+$ (phosphorus) emitters. The new method is industrially applicable with no substantial increase in cost or process time.

The method employs an ultrathin silicon oxide between the emitter and the $\mathrm{SiN}_{\mathrm{x}}$. The oxide is created by wet chemical means, i.e., by immersion in nitric acid (at room temperature): NAOS or nitric acid oxidation of silicon. An almost 6-fold enhancement in the lifetime and $60 \mathrm{mV}$ higher implied $\mathrm{V}_{\text {oc }}$ is observed for lifetime test devices after firing. These values outperform even the results obtained using thermal $\mathrm{SiO}_{2} / \mathrm{PECVD} \mathrm{SiN}_{\mathrm{x}}$ stacked layers as a passivation method. Since the method employs a low-temperature oxidation process, possible deterioration of, e.g., the base material, is minimized.

As reported previously [3], an enhancement in solar cell efficiency of about $2 \%$ absolute was achieved using the NAOS/SiN $\mathrm{S}_{\mathrm{x}}$ passivation method as compared with the standard $\mathrm{SiN}_{\mathrm{x}}$ passivation method industrially used for phosphorus emitter passivation. The profound effect on boron emitter passivation can be observed in the strong enhancement of the IQE for wavelengths below $700 \mathrm{~nm}$. Consequently, the $\mathrm{V}_{\mathrm{oc}}$ and $\mathrm{J}_{\mathrm{sc}}$ of the cell are increased.

This paper presents results on a similar type of cell.
We demonstrate that an alternative wet chemical process for creating the $\mathrm{SiO}_{2}$ passivation layer facilitates a further enhancement of the $\mathrm{V}_{\text {oc }}$ by 4 to $5 \mathrm{mV}$. The $\mathrm{V}_{\text {oc }}$ has an average value of $634 \mathrm{mV}$ and a peak value of $639 \mathrm{mV}$.

\section{EXPERIMENTAL}

Cells were prepared from n-type $\mathrm{Cz}$ material according to a standard protocol that is illustrated in Figure 1. One group of cells (Group A) received our original passivation process that was reported by Mihailetchi et al. [3]. Another group (Group B) received an improved wet chemical process. A selection of these wafers was not metallized but they did receive the standard heat treatment for firing through of the metal electrodes. This step is necessary to enhance the passivation in these cells, probably by releasing hydrogen from the $\mathrm{SiN}_{\mathrm{x}}$ layer [3]. The unmetallized cells are used to assess the effect of the chemical treatment while excluding the effects of metallization.

\begin{tabular}{|c|}
\hline Alkaline etch and wafer clean \\
\hline Diffusion of emitter and BSF \\
\hline $\begin{array}{c}\text { Wet chemical process and } \\
\text { SiN }_{\mathrm{x}} \text { coating (both sides) }\end{array}$ \\
\hline Screen printing metal paste \\
\hline Firing through \\
\hline
\end{tabular}

Figure 1: Major process steps for making industrial screen printed n-type solar cells. 
The structure of the fabricated n-type cells is illustrated in figures 2 and 3. The rearsides of the cells are passivated by a phosphorous back-surface field and a SiNx layer. The rearside metallization has an open structure that can enhance the internal reflection.

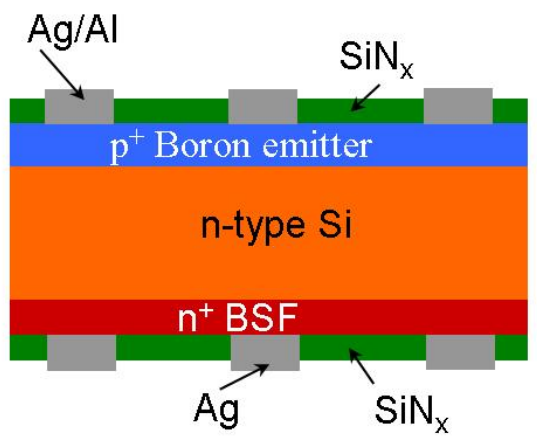

Figure 2: Schematic cross-section of the n-type solar cell.

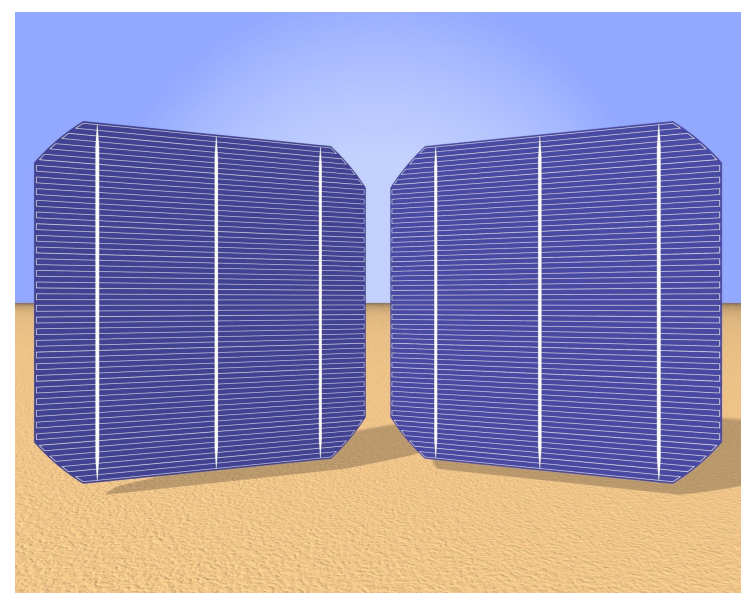

Figure 3: Artistic impression of the resulting n-type silicon solar cells with an $\mathrm{H}$ pattern front- and rearside.

\section{RESULTS AND DISCUSSION}

Figure 4 presents implied $\mathrm{V}_{\mathrm{oc}}$ values as derived from QSSPC measurements [4] on unmetallized cells. The cells in Group B with the improved wet chemical passivation had an average implied $\mathrm{V}_{\mathrm{oc}}$ of $652 \mathrm{mV}$ while the highest recorded value was $657 \mathrm{mV}$. By contrast, Group A had an average of $642 \mathrm{mV}$ and a peak value of $645 \mathrm{mV}$. These measurements demonstrate a clear advantageous effect of the chemical process used for Group B on the implied $\mathrm{V}_{\mathrm{oc}}$. The standard deviation was also lower.

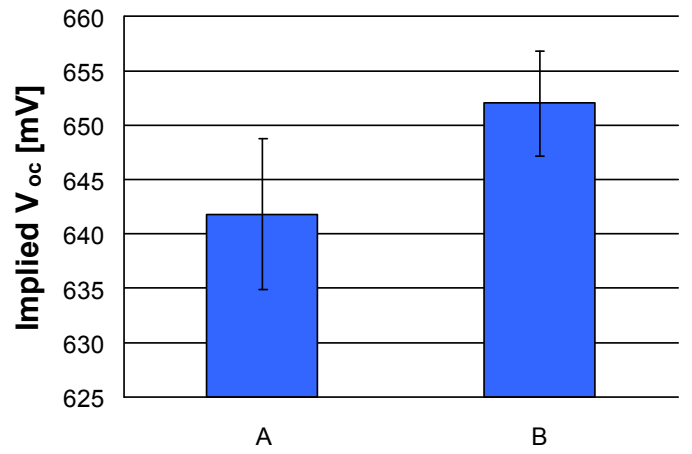

Figure 4: Implied $V_{o c}$ of unmetallized cells as measured by QSSPC at an incident radiation intensity of 1 sun, comparing two passivation processes. A is our previously reported process and B is the improved process. For each treatment the results from 5 cells were averaged. The error bars depict the standard deviation.

Figure 5 presents the $V_{o c}$ values of completed cells (with metallization) as measured with a Class A solar simulator. These measurements shows a $4 \mathrm{mV}$ gain in $\mathrm{V}_{\mathrm{oc}}$ in Group B. The average $\mathrm{V}_{\text {oc }}$ in Group B was $634 \mathrm{mV}$ and the highest recorded value was $639 \mathrm{mV}$. These values are higher than those of Group A and, accordingly, they also represent a significant improvement on our previously obtained results with this type of cell [3].

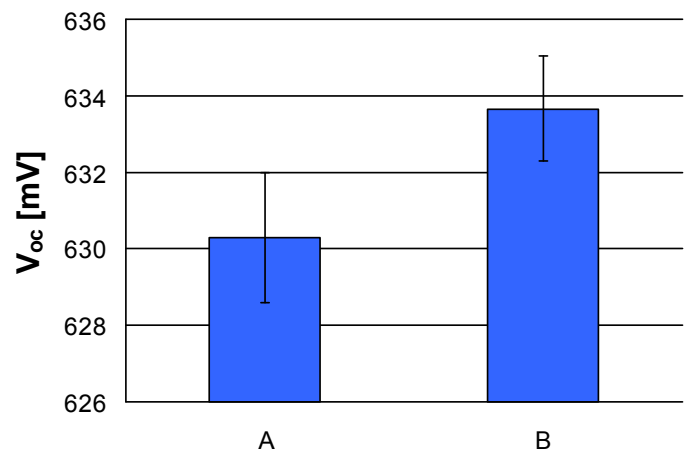

Figure 5: $\mathrm{V}_{\mathrm{oc}}$ of completed cells as measured with a Class A solar simulator, comparing two passivation processes. For Group A and Group B the results from 10 and 9 cells were averaged, respectively. The error bars depict the standard deviation.

The $V_{\text {oc }}$ enhancement that was demonstrated will have a beneficial influence on the overall efficiency of the cell. Table 1 presents the result for one of the best cells that was obtained, as measured by an independent institute. It should be noted that, because of the open rear-side, the reflection properties of the surface that the wafer is placed upon have an impact on the measured efficiency. 
Table 1: Solar cell parameters measured by Fraunhofer ISE CalLab for a cell made with the improved NAOS, for a particular rear-side reflection surface.

\begin{tabular}{|c|c|c|c|c|c|}
\hline Type & $\begin{array}{c}\text { Area } \\
{\left[\mathbf{c m}^{2}\right]}\end{array}$ & $\begin{array}{c}\mathbf{J}_{\text {sc }} \\
{\left[\mathbf{m A ~} \mathbf{~ c m}^{-2}\right]}\end{array}$ & $\begin{array}{c}\mathbf{V}_{\text {oc }} \\
{[\mathbf{m V}]}\end{array}$ & $\begin{array}{c}\mathbf{F F} \\
{[\mathbf{\%}]}\end{array}$ & $\begin{array}{c}\boldsymbol{\eta} \\
{[\%]}\end{array}$ \\
\hline $\mathrm{Cz}$ & 155.7 & 37.5 & 634 & 79.9 & 18.5 \\
\hline
\end{tabular}

Figure 6 presents the IQE of two of the best cells made with the original and the improved NAOS. Since the absorption coefficient of $\mathrm{Si}$ for blue light (short wavelength photons) is very large, this light is absorbed directly near the front surface of the cell. Therefore, the IQE for short wavelength photons strongly reflects the recombination at the front surface of a cell, thus, it reflects the passivation of the boron emitter in the solar cells. The IQE of the solar cell passivated using improved NAOS shows an improvement for wavelengths below 0.6 $\mu \mathrm{m}$, as compared with the original NAOS. This observation indicates that the improvement in the boron emitter passivation is the cause for the enhanced solar cell performance

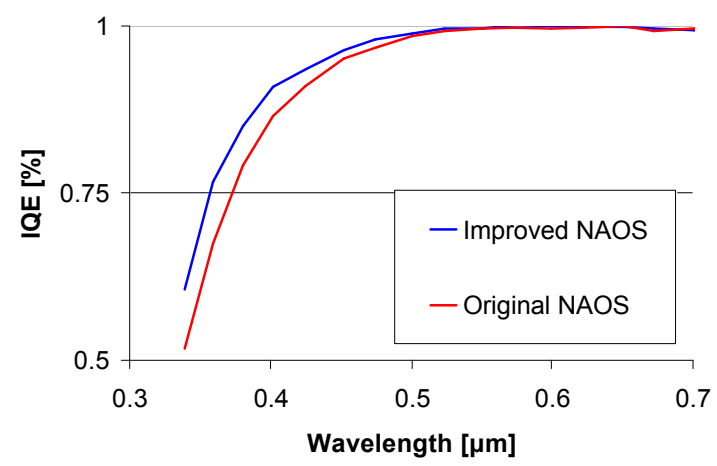

Figure 6: IQE of cells made with the original and the improved wet chemical passivation.

\section{CONCLUSIONS}

We have presented an industrially feasible process to fabricate n-type solar cells on large area $\left(125 \times 125 \mathrm{~mm}^{2}\right)$ multicrystalline and $\mathrm{Cz}$ substrates that involves screen printing and firing through. The passivation of these solar cells was improved with an alternative wet chemical process that is used to grow the $\mathrm{SiO}_{2}$ passivation layer. Both QSSPC and solar simulator measurements demonstrate an enhancement of the (implied) $\mathrm{V}_{\mathrm{oc}}$. The process improvements have yielded a new record efficiency of $18.5 \%$ (for a particular rear reflection surface) that was measured by an independent institute.

\section{ACKNOWLEDGEMENTS}

This work was supported by the Dutch agency for energy and the environment SenterNovem.

\section{REFERENCES}

[1] D. MacDonald, L.J. Geerligs, Applied Physics Letters 2004, 85, 4061.

[2] J.E. Cotter et al., $15^{\text {th }}$ Workshop on Crystalline Silicon Solar Cells \& Modules: Materials and Processes 2005, 3.

[3] V.D. Mihailetchi, Y. Komatsu, L.J. Geerligs, Applied Physics Letters 2008, 92, 063510.

[4] R.A. Sinton, A. Cuevas, Applied Physics Letters 1996, 16, 2510. 